\title{
Appraisal of Suitability of the "Mista Ali Granite of Jos Plateau State Nigeria" as an Aggregate for Construction Material using Selected Testing Parameters
}

\author{
Joro Joshua Dung ${ }^{1}$, Achuenu Ifeanyi ${ }^{2}$, Akinola Abayomi Paul ${ }^{3}$ \\ ${ }^{1}$ Lecturer, ${ }^{2}$ Technologist, ${ }^{3}$ Lecturer \\ Department of Mining Engineering, University of Jos, Nigeria
}

\begin{abstract}
ABSTRCT
The appraisal of the suitability of some selected granite deposits for aggregate stone production within the basement complex of Mista Ali of Jos Plateau state for road construction was carried out. Aggregate samples obtained from the deposits were analyzed in the laboratory to determine their mechanical properties by a series of composite testing parameters using aggregate abrasion value (AAV), aggregate impact value (AIV), aggregate crushing value (ACV), specific gravity (SG) and water absorption (WA) as contained in BS812, and AASHTOT96-92. It was found out that the granite deposits possess certain desirable aesthetic and visual characteristics. Also, the percentage mineralogical compositions of the studied samples were examined. The results had shown that Jolex Construction (JC) Quarry site has a good percentage composition of orthoclase and plagioclase content which reduces the rate of wearing and tearing. The results of the laboratory analyses on the aggregate sample indicated that the technical features measured such as the strength, density, and water absorption capacity of the "Mista Ali granite deposits" at the Jolex construction Quarry site are suitable for aggregate stone for road construction when compared with the globally accepted standard. The result of the appraisal will be useful and serve as database to prospective investors in aggregate stone quarrying.
\end{abstract}

Keyword: Appraisal, Suitability, Aggregate, Granite.

\section{0: INTRODUCTION}

\section{1: Background to the Study}

The suitability of granite for an aggregate quarry depends on factors that discriminate or qualify it as a construction material in building, civil and other engineering works. These factors are very important and must be considered when siting a "quarry" for aggregate production. These factors are grouped into three namely: physical, mechanical, and chemical properties of the granite. The physical properties include electrical, magnetic and radioactivity of the granite. The mechanical properties include the elastic modulus of granite, the strength, stress, and the strain of granite (Hook, 1666). In the above properties, the measured strength is considered, using various testing machines. The chemical property includes the composition of the rock and how they are packed during crystallization of magma, also called inter-crystallinity, with respect to temperature and it is observed under thin section using petrologic microscope, under both crossed and plane polarized light. The structure of granite also contributes to the engineering properties of the granite and hence a factor when considering a site for an aggregate quarry. These structures include the joint, fault, fracture, veins, lineation and foliation.

The term granite can be studied and defined according to the users. In an introductory course, granite is coarse grained, light-coloured, igneous rock composed mainly of feldspar and quartz with minor amounts of mica and amphibole minerals. In petrology granite is a plutonic rock in which quartz makes up between 10 and 50\% of the felsic compound and alkali feldspar accounts for 65 to $90 \%$ of the total feldspar content. For commercial purpose, granite is quarried or exploited by the people who sell and purchase cut stone for structural and decorative use. The durability property and the abundance of granite make it preferred choice of mineral over the others especially for construction purposes. The primary minerals found in granite include quartz, plagioclase feldspar, potassium feldspar, hornblende and micas (Amethyst, (2004). Quartz is mostly the last mineral to crystallize and fills the extra space between the other minerals; its hardness lacks chemical reactivity while lack of cleavages give a significant amount of its durable property. Granite is actually rather radioactive and has 5 to 20 times concentration of uranium compound compared to other common rock types. Some health concern exists in areas that are rich in granitic terrain, as background radiation is enhanced by the occurrence of large granite bodies. However, uranium is generally not concentrated enough to make granite uranium ore. The leaching and erosion of granite has helped to produce most of the uranium ore 
deposit around the world. Quartz is responsible for radon gas, being the by- product of radioactive decay radium found in all granites (Minipal, 2014).

Furthermore, granite is a natural product whose beauty comes from porosity, crystalline quartz structure, fissures and movement of the conglomerate, mineral composition, veining and grain size. Granite is formed by molten magma deep within the earth under great pressure and heat (Wills, 2006). Granite is very dense and in making massive countertop, in large slab sizes and varieties are available from all over the World. It is also a porous material as well as permeable and has massive capillary, leading to cleaning damages efflorescent staining, water marks, soap stains, surface haze, bacteria and mold, colonies resulting in odour and health risks and sink rail splitting from rod corrosion. Porosity also results to water damage in granite, hydrolysis and hydration; even granite rocks possess several physical and mechanical properties that might influence the use of granite as a construction material. Generally, granites find applications in structure and civil engineering work. The physical and mechanical properties of granite are functions of its texture and mineralogy. The properties may as well affect quarrying operation tunneling mining, slope stability and the use of granite as construction material. However the strength of granite rock decreases with increase in water content due to reduction in the coefficient of internal friction of the rock particles. In addition, the presence of water in rock increases the deformability of the rock mass Ojo and Olaleye, (2004). The older granite of Nigeria varies in composition ranging from tonalite, granodiorite, granite, syenite and charnockite rock.

Granite aggregates are crushed hard rock of granular structure, being the most common on Earth. Granite rock comes from magma that erupted on the ground surface and then hardened. Good properties of granite make it the most popular building material. In terms of its technical characteristics granite is solid (grades 800-1200) and highly solid (grades 1,400-1,600), frost resistant (grades 300400 ), with low flakiness index (5-23\%), of the 1st class in terms of radionuclidity [A (eff) $<370 \mathrm{nBq} / \mathrm{kg}$ ]. The radionuclide content, harmful components and additives indicators are either absent or do not exceed norms, the fact of which is proven by corresponding certificates and conclusions issued after conducted researches. It is the best aggregate for high-grade concrete. Granite is also used as a decorative stone. It can be grey, red, or pink and has a lot of shades. After polishing it acquires a beautiful smooth surface. Granite is mostly composed of feldspar, quartz and mica crystals, the content of which influences the color and shades of the stone.

\subsection{Location and Accessibility}

The study area "Mista Ali" lies approximately between latitudes N9 ${ }^{0}-56$ '45.1"and between longitudes E8 ${ }^{0}-56$ '28.4" covering a total area of about $282 \mathrm{~km}^{2}$. The area is easily accessible all year round as there are good network of tarred and graded roads within the area.

\section{3: STATEMENT OF RESEARCH PROBLEM}

The major issues that are critical in siting a quarry for aggregates production are

i. Proximity to the market place from the quarry,

ii. Accessibility of the market place to the quarry site,

iii. Prevalent political atmosphere in the area

iv. Disposition of the local people to physical development and environmental sustainability

v. Security of life and property

\section{4: AIM AND OBJECTIVES}

The aim of this research work is to appraise the suitability of the granite of Mista Ali, Bassa Local Area of Jos Plateau State for "quarrying" as construction material.

This would be accomplished through the following objectives:

i. Determination of Abrasion value of granite using Los Angeles Testing Method.

ii. Assessment of Impact value of granite using Impact Testing Method.

iii. Determination of Crushing Value of granite using Crushing Testing Method

iv. Evaluation of Flakiness of granite using Flaking Index Test

v. Determination of density of granite using picnometer 


\section{5: Scope Of The Present Work}

This research work investigates the compressive stress using Impact Aggregate test, Los Angeles Abrassive test, Crushing Value, Frankling Index test to determine the suitability of the Mista Ali granite for quarrying as aggregate material.

\section{6: Assumption}

The suitability of granite as an aggregate quarry is based on assumption that if all other things being equal, it is the most competent, hard material with high compressive strength and can withstand stress with application of load than other rocks.

\section{0: LITERATURE REVIEW}

\section{1: The Geology of Younger Granites Province Of Nigeria}

The Younger Granites province of Nigeria which mostly occurs as ring complex has demonstrated a consistent succession of magmatic activities from volcanism to plutonism associated with the emplacement of mainly granite melts at high levels in the crust. The most striking petrographic feature of the whole province is the overwhelmingly acid nature of the rocks and the similarity of the rock types found in all areas. More than 50 complexes occur in Nigeria varying from $<2$ to $>25 \mathrm{~km}$ in diameter and over $95 \%$ of the rocks can be classified as rhyolites, quartz-syenites or granites, with basic rocks forming the remaining $5 \%$. Many of the rocks have strongly alkaline to per alkaline compositions, others are aluminous to paraluminous. The ring complexes cover a total area of about 7,500 $\mathrm{km}^{2}$ with individual massifs varying from 1,000 to $<1 \mathrm{~km}^{2}$. Each of the ring-complexes, whether they consist of overlapping centers as Ningi-Burra, or individual centers such as Riruwai began as chains of volcanoes. The Younger Granites are discordant high level intrusion, initial stages in development of the complexes involved intrusion of vast amount of acid lavas and tuffs, now only partly preserved as a result of subsidence along ring faults. Almost everywhere these rhyolitic rocks directly overlie the metamorphic basement, which means that the Younger Granites were emplaced in uplifted areas that were undergoing erosion. Granitic ring dykes are the major component of most complexes, ranging from $5 \mathrm{~km}$ or less to over $30 \mathrm{~km}$ in diameter and varying in plan from the polygonal to circular or crescent, and through.

\subsubsection{General Geology of Jos Plateau State}

The general geology of Jos-Plateau was described and elaborated by Macleod et al (1971). It is an isolated upland with an elevation of $1219.2 \mathrm{~m}$ covering an area of $8600 \mathrm{~km}^{2}$. The Jos Plateau is part of the Pre-Cambrian to Mid-Cambrian and Jurassic northern Nigerian crystalline basement rock with patches of Cenozoic volcanic rocks (Table 1).

The Jos- Bukuru complex occupies the central portion of Jos-Plateau. It consists of all rock types in the province except the basic and intermediate rock. Igneous activities in this complex is represented by two cycles, these are: fayalite bearing granite and porphyry hastingstitebiotite granite and five other phases of biotite granite constitute the first igneous cycle. The second igneous cycle whose rocks cross-cut the earlier one is made up of fayalite, hastingstite, granite porphyry, hastingstite biotite granite and four phases of biotite. The boundary between them is gradational. In most cases indistinguishable.

Jos biotite granite is the largest individual intrusion which has been recognized in the younger granite province, covering an area of 110 sq miles. On the basis of similarity of age, structural relations and petrology, the Jos biotite granite appears to be closely related to the early hornblende biotite granite and granite porphyry. Megascopic observation reveals the rock sample as being coarse grained porphyritic and generally gray in colour. The minerals observed are feldspar (60\%) with average grain size of $3.1 \mathrm{~mm}$ and biotite (about $10 \%$ ) with average grain size of $3.1 \mathrm{~mm}$ and biotite (about $10 \%$ ) with an average grain size of $42 \mathrm{~mm}$. 
International Journal of Advances in Scientific Research and Engineering (ijasre), Vol 7 (9), September -2021

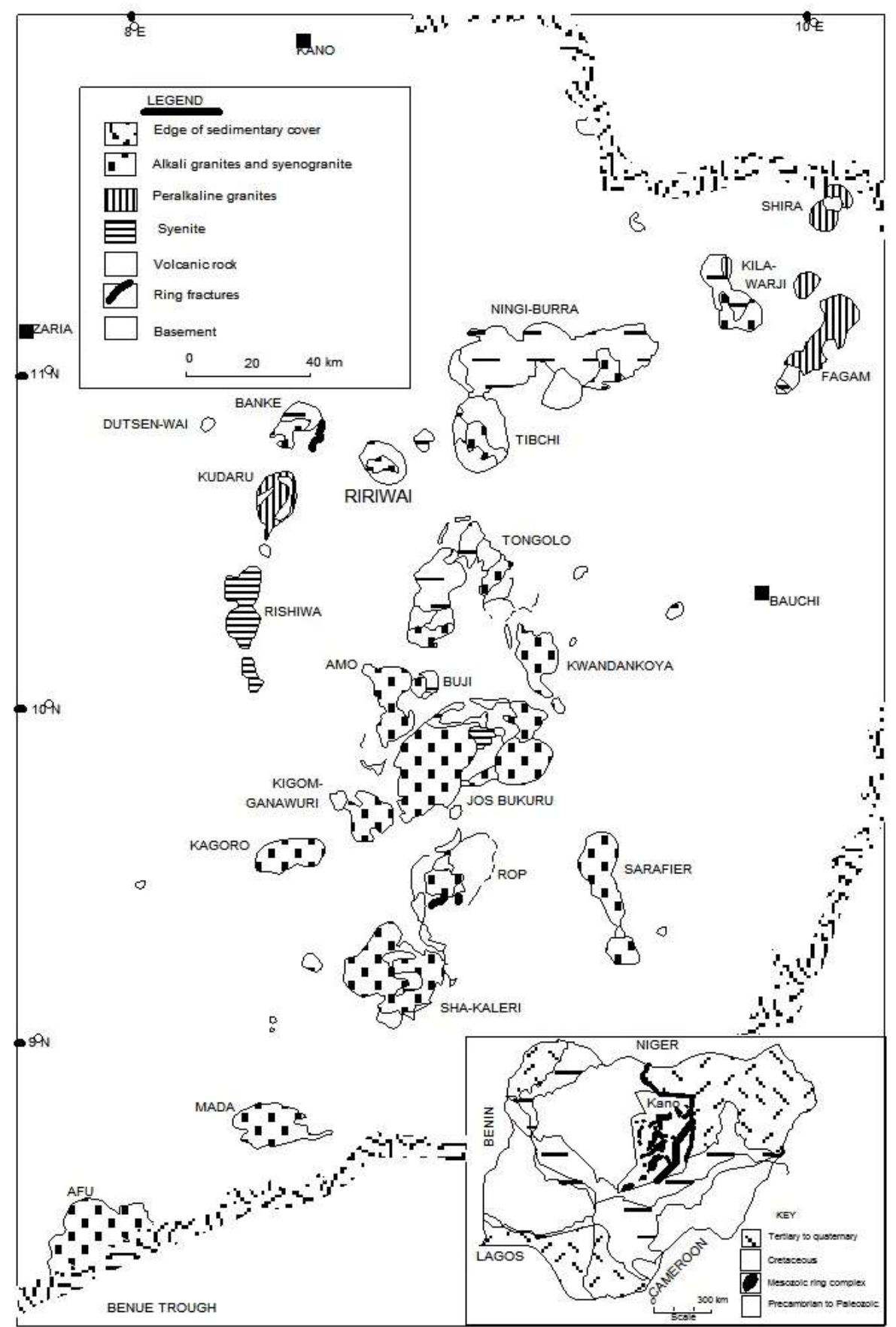

Figure 3: Locality map and general geological setting of the Younger Granite ring-complexes in Nigeria (after Kinnaird, 1985). Inset: Geological sketch map of Nigeria indicating the location of the Younger Granites province 
International Journal of Advances in Scientific Research and Engineering (ijasre), Vol 7 (9), September -2021

Table 1: A generalized succession of rocks on Jos Plateau

\begin{tabular}{|l|l|l|}
\hline \multicolumn{1}{|c|}{ Age } & \multicolumn{1}{c|}{ Rock } & \multicolumn{1}{c|}{ Description } \\
\hline Quaternary & Newer basalt & Lava flow and volcanic cones \\
\hline Tertiary quaternary & Older basalt & $\begin{array}{l}\text { Lave flow, now largely decomposed overlying } \\
\text { alluvium }\end{array}$ \\
\hline Jurassic & Younger granite & Granite porphyrites and rhyolite \\
\hline Pre-Cambrian to lower Paleozoic & Crystalline basement & Migmatite gneiss and older granite \\
\hline
\end{tabular}

(Adopted from Macleod, 1979)

\subsubsection{Emplacement of the Younger Granite Complex}

The emplacement of the younger granites consists of two cycles. These are ring faulting and cauldron subsidence, these are the major control that governs the emplacement of the younger granites. These controls have operated during both the volcanic and plutonic stages of the explosive cycle.

Volcanic rocks represent the earliest igneous activity and are intruded by Porphyries, granites and less commonly syenites. These are confined to a roughly circular area bounded by a ring dyke or ring fault. The ring dyke is the main structural feature of the complex and controls the distribution of the early volcanic rocks and to some extent the later immusion. Two stages can be distinguished in the volcanic cycles. These are the early ryolites and associated pyroclastic which are typical products of spasmodic rent eruption and the late Rhyolites which are formed by large scale cauldron subsidence. The initial stage of development of the complex was marked by the extrusion of vast quantities of acid lava and welded tuffs, which are partially preserved as a result of subsidence along the ring faults.

The early rhyolites shows a bedded sequence, welded riff, bedded aid fall riffs, Agglomerates and occasional basalt, and trachytes. These are typical of spiractic activity from single central vent volcanoes or from groups of elongated vents along ring fractures. The most conspicuous structural features of the bedded volcanic rocks are tectonic in origin imposed by cauldron subsidence and Igneous intrusive.

\subsection{Nature of This Study}

\subsubsection{Production of Construction Aggregate}

Primary aggregates are produced from two main types of quarrying operation, crushed rock and sand and gravel. They are typical extracted by surface quarrying with underground mining of aggregates relatively rare. Any overburden is removed using combination of hydraulic excavators ripping and blasting. Crushed rock aggregates are produced from quarries that are much larger and deeper than sand and gravel pits. Crushed rock aggregate is normally extracted using blasting, whereas sand and gravel is usually extracted by front end loaders, bull dozers with rippers or self-elevating scrapers. The excavated material is delivered to production plant in a firm suitable for processing.

Production of crushed rock aggregate involves screening (scalping) to remove fines and screening to produce material with specified size grades. Crushing is carried out to reduce the size of the excavated material from large blocks up to a meter across to a size finner than 20 to $50 \mathrm{~mm}$. Production of sand and gravel involves washing and scrubbing to remove clay, separation of the sand fraction by screening, grading of the gravel;, sand classification and dewatering and crushing of any oversize gravel to produce a saleable product. Washing removes silt and clay (material finer than $0.063 \mathrm{~mm}$ ) which is present either as surface coating or as clay-bound agglomerates that need to be broken down, Mitchell (2007).

\subsubsection{Standards and Test Methods}

The testing of construction aggregate is carried out to international standards. The quality of quarry products used in the UK is controlled by the European standards for aggregate for concretes, mortar, and asphalt and road construction. The key parameters for aggregates are particle size and shape, physical and mechanical properties and durability. The laboratory evaluation of construction aggregate ranges from simple and low cost to sophisticated and expensive testing. A useful manual for the testing of construction materials including, aggregate was published by the British Geological survey in 1994.

\subsubsection{Particle Size Distribution (Grading)}

The particle size distribution or grading is a fundamental property for all construction aggregates and often defines the products. Grading is usually carried out by sieve analysis. 


\subsection{Geology of the Study Area}

The study area lies in central Nigeria. The granitic rocks under investigation are located at Mista Ali village, Bassa local Government Area. The Nigeria basement complex extends westwards and is continuous within the Dahomey-Togo-Ghana region. To the east and the south the basement complex is covered by the Mesozoic - Recent sediments of the Dahomey and Niger Water Basin. The basement complex of Nigeria is composed predominantly of magmatic and granite gneiss, quartzites, slightly migmatised to unmigmatised-metasedimentary schist and meta-igneous rocks, charnocketic, gabboric and dioritic rocks and members of old granites, granodiorite and synite. Granite gneisses are found abundant in central Nigeria (Kogbe, 1979).

\section{4: AGGREGATE}

Any naturally occurring geological material can be used as construction aggregate as long as it satisfies the requirements of the end - use specification. Primary aggregates are produced from two main sources, "crushed rock" and "sand and gravel". Crushed rock aggregates are produced from hard strong rock formation including igneous (andesite, basalt diorite, dolerite, gabbro, granite, rhyolite, tuff), metamorphic (hornfels, gneiss, quartzite schist) and sedimentary (sandstone, limestone) rock. Most limestone and dolomite are hard and durable and useful for aggregates. The quality of the limestone resources and their ease and economy of working may be affected by a number of geological factors such as waste content, dolomitisation and degree of faulting and folding. The suitability of sandstone for aggregate use depends on its strength, porosity and durability. Many types of sandstones are too porous and weak to be used other than as sources of constructional fill. In general, older more indurated sandstones exhibit higher strengths and are suitable for more demanding aggregate uses. Igneous rocks tend to produce strong aggregates with a degree of skid resistance and are hence suitable for many road surfacing applications as well as for use in the lower parts of the road pavement. The high strength and attrition resistance of certain igneous rocks results in their use as railway ballast, (BGS, 2013).

Sand and gravel deposits are accumulations of the more durable rock fragments and mineral grains which have been derived from the weathering and erosion of hard rocks, mainly by glacial and river action, but also by wind. The term gravel (coarse aggregate) is used to define particles between 4 and $8 \mathrm{~mm}$ and the term "sand" (fine aggregate) for material that is finer than $4 \mathrm{~mm}$ but coarser than $0.6 \mathrm{~mm}$. The properties of gravel and to a lesser extent sand largely depend on the properties of the rocks from which they were derived. However water action is an effective mechanism for wearing away weaker particles as well as separating different fractions. Most sands and gravel are composed of particles that are durable and rich in silica (1artz, quartzite and flint). Other rock types, mainly limestone may also occur in some land - won deposits including deterious impurities such as lignite, mudstone, chalk and coal (BGS, 2013).

\subsubsection{Classification of Intact Rock}

For engineering uses, attempts were made to classify intact rocks based on an individual property, such as uniaxial compressive strength, modulus, sonic velocity and point load strength index, notably by Coates (1964), Hansagi (1965), Deere and Miller (1966), Stapledon (1968), Frankliin et al. (1971), Bieniawski (1978) and ISRM (1978, 1981). Table 2 presents some of these classifications on the basis of compressive strength of intact rocks. Different levels of grading in classifying the rocks have been suggested by various authors over the years. A rock is differentiated from a soil when its uniaxial compressive strength is not always relevant to field engineers; these have served to understand the upper bound strength response of rocks. Intact rocks have also been classified on the basis of modulus of deformation alone as per Table 3.

Table 2: Uniaxial compressive strength classifications of intact rocks by authors

\begin{tabular}{|c|c|c|}
\hline & Classes & Authorss \\
\hline 1 & Very low strength & \multirow{5}{*}{ Decree \& Miller (1966) } \\
\hline 2 & Medium strength & \\
\hline 3 & Low strength & \\
\hline 4 & High strength & \\
\hline 5 & Very high strength & \\
\hline 1 & Very low strength & \multirow{5}{*}{ Bieniawski (1978) } \\
\hline 2 & Low strength & \\
\hline 3 & Medium strength & \\
\hline 4 & High strength & \\
\hline 5 & Very high strength & \\
\hline
\end{tabular}


International Journal of Advances in Scientific Research and Engineering (ijasre), Vol 7 (9), September -2021

\begin{tabular}{|l|l|l|}
\hline 1 & Very low & I \\
\hline 2 & Low & \\
\hline 3 & Moderate & SRM (1978) \\
\hline 4 & Medium & \\
\hline 5 & High & \\
\hline 6 & Very high & \\
\hline
\end{tabular}

Source: Deere and Miller, 1966

Table 3: Classification based on Modulus of Deformation

\begin{tabular}{lll}
\hline Class & Modulus of deformation $\left(\mathrm{MPa} \times 10^{3}\right)$ & Description of deformity \\
\hline 1 & $<5$ & Very high \\
2 & $5-15$ & High \\
3 & $15-30$ & Moderate \\
4 & $30-60$ & Low \\
5 & $>60$ & Very low \\
\hline
\end{tabular}

Source: Deere and Miller, 1966

The classification proposed by Deere and Miller (1966) for intact rocks is based on the combined influence of the uniaxial compressive strength $\delta_{c i}$, (Table 4) and tangent has been widely recognized as a realistic and useful engineering classification which takes into account more than one measurable property at a time. Based on these properties, first letter refers to the compressive strength range and the second letter refers to the modulus ratio i.e. $E_{t i} / \delta_{c i}$ range, as shown in Table 5. Each intact rock type has its specific zone in the region of $\delta_{c i}$ and $E_{t i}$. The limits of the various classes of intact rocks are therefore based on meaningful and representative limits. When intact rocks are classified the effect of seepage pressure or confining pressure is not considered.

Table 4: Strength Classification (Deere and Miller 1966)

\begin{tabular}{|l|l|l|}
\hline Class & Description & Uniaxial compressive strength, $\delta_{c i}(\mathrm{MPa})$ \\
\hline A & Very high strength & $>224$ \\
B & High strength & $112-224$ \\
C & Medium strength & $56-112$ \\
D & Low strength & $28-56$ \\
E & Very low strength & $<28$ \\
\hline
\end{tabular}

Source: Deere and Miller 1966

Table 5: Modulus Ratio and Classification

\begin{tabular}{lll}
\hline Class & Description & Modulus ratio \\
\hline $\mathrm{H}$ & High Modulus ratio & $>500$ \\
$\mathrm{M}$ & Medium modulus ratio & $200-500$ \\
$\mathrm{~L}$ & Low modulus ratio & $<200$ \\
\hline
\end{tabular}

Source: Deere and Miller 1966 


\subsection{Rock Mass Classification}

The engineering behavior of a rock mass is controlled by more than one factor; the influence of each of these factors vastly differs. Any attempt to classify rock based on a single parameter like joint frequency will not be satisfactory. Of the various rock mass classifications suggested for engineering use, those suggested by Terzaghi (1946), Deere (1964), Beniawski (1973), Barton et al. (1974) and ISRM (1981) are commonly adopted. A descriptive rock mass classification (Table 6) proposed by Terzaghi (1946) has been useful for tunnels and for a particular type of construction technique with steel supports, it could not be adopted for foundations and slopes and did not give any indication of strength or modulus rock mass. But Terzaghi's classification paved way to recognize a number of factors such as joint orientation the nature of joint surface and the nature of joint filling influencing the rock mass behavior.

Core recovery has been in use to get an indication of the quality of the rock mass as a result of the loss of core due to washing out of the soil from the joints during drilling operation and is the total core strength expressed as the percentage of the drilled depth of a bore. No correlation exists to link core recovery with the compressive strength or modulus of deformation of the rock mass. Number of joints, their spacing, inclination and the nature of joint material is not reflected in the core recovery. Even though it has not served as an engineering parameter for the purpose of design it does form one of the input data to be recorded on the bore log chart. When Rock Quality Designation (RQD) was suggested by Deere (1964), this was readily accepted and today it is being used to classify the quality of rock mass in preference to core recovery.

\section{Table 6: Classification of in Situ Rock for Predicting Tunnel Support Requirements}

Term Description

Intact

Stratified

Moderately jointed

Blocky and seamy

Crushed

Squeezing

Swelling

\section{Rock contains neither joints nor hair cracks}

Rock consists of individual strata with little or no resistance against separation along the boundaries between strata

Rock contains joints and hair cracks, but the blocks between joints are locally grown together or so intimately interlocked that vertical walls do not require lateral support.

Rock consists of chemically un-weathered rock fragments which are entirely separated from each other and imperfectly interlocked. In such rock, vertical walls may require support.

Chemically un-weathered rock has the character of crusher run material

Rock slowly advances into the tunnel without perceptible volume change.

Rock advances into the tunnel chiefly on account of expansion caused by minerals with a high swelling capacity. 


\section{0: METHODOLOGY}

\section{1: INTRODUCTION}

This chapter discusses the procedure used in carrying out the survey and subsequent analysis of results obtained. It covers a brief description of the survey, the procedure of sample selection, the process through which the mapping had been developed and administered. It also includes a description of the techniques used in compiling, collating and analyzing the data generated from the study.

\section{2: SAMPLE DESIGN}

The rock type used for this research is biotite granite. These rocks are felsic, coarse to very coarse in grain size. The rock was selected for analysis out of many other types because of their abundance and ease of sampling.

$10 \mathrm{~kg}$ of the five samples from each point were picked using $10 \mathrm{~kg}$ sledge hammer on the rock body to realize boulder size by random sampling method. Each sample was subjected to same types of laboratory test: chemical analysis, and test machine. Both petrographic and petrology techniques, which are systematic description of rocks based on observations in the field, hand specimen, and in thin section, were employed during the research. In assessing the potential of a rock for use as an aggregate, the first requirement is a full petrographic study of the rocks, identifying its mineralogy, grain size, texture, fabric (sum of textural and structural), and the weathering states which are determined by the geological processes that formed the rock. These processes decide the ways in which a rock may fail, and also help to optimize production of good quality aggregates.

\section{3: SAMPLE TECHNIQUE}

\subsection{1: Method of Data Collected}

The data used in the study were from primary and secondary sources. The secondary data were collected or obtained from various sources such as textbooks, Journals, and internet, etc., while the primary data were obtained from field during geological mapping.

\subsection{2: Method Employed in Data Collection}

In building construction and other engineering disciplines, such as road surfacing, there are several important considerations as to whether a rock is suitable or not for use as aggregate. Aggregate used in the surface course (running surface) of road must be resistant to the polishing action of vehicle tyres, otherwise the road can become slippery, especially when wet. It is essential that aggregates used in construction purposes are strong and durable. The properties used to assess the suitability of rocks as aggregate material include the following tests: strength, water absorption, flakiness, abrasion resistance to weathering. Laboratory study included petrographic analysis of the rocks, first by thin sectioning and examination of the slides under plane and cross polarized light. The strength of the aggregates were evaluated by a series of composite tests including aggregate abrasion value (AAV), aggregate impact value (AIV), aggregate crushing value (ACV), specific gravity (SG) and water absorption (WA) as contained in BS812, and AASHTOT96-92. Aggregate abrasion value was determined using Los Angeles machine.

\section{4: AGGREGATE ABRASION VALUE DETERMINATION (AAV).}

The test sample consists of clean aggregates dried in oven at $105^{\circ}-110^{\circ} \mathrm{C}$. The sample should conform to any of the gradings.

(i) Select the grading to be used in the test such that it conforms to the grading to be used in construction, to the maximum extent possible.

(ii) Take $5 \mathrm{~kg}$ of sample for gradings $\mathrm{A}, \mathrm{B}$, and $\mathrm{C}$.

(iii) Choose the abrasive charge, depending on grading of aggregates.

(iv) Place the aggregates and abrasive charge on the cylinder and fix the cover.

(v) Rotate the machine at a speed of $30-33$ revolutions per minute. The number of revolutions is 500 for gradings A, B, and $\mathrm{C}$. The machine should be balanced and driven such that there is uniform peripheral speed.

(vi) The machine is stopped after the desired number of revolutions and material is discharged to a tray.

(vii) The entire stone dust is sieved on $1.70 \mathrm{~mm}$ IS sieve.

\section{OBSERVATIONS:}

Original weight of aggregate sample $=\mathrm{W}_{1} \mathrm{~g}$ 
International Journal of Advances in Scientific Research and Engineering (ijasre), Vol 7 (9), September -2021

Weight of aggregate sample retained $=\mathrm{W}_{2} \mathrm{~g}$

Weight passing $1.7 \mathrm{~mm}$ IS sieve $=\mathrm{W}_{1}-\mathrm{W}_{2} \mathrm{~g}$

Abrasion Value $=\left(\mathrm{W}_{1}-\mathrm{W}_{2}\right) / \mathrm{W}_{1}$ X 100

\section{TEST SIGNIFICANCE:}

1. To choose the best type of aggregate due to abrasion value.

2. To calculate the hardness of aggregates.

\section{APPARATUS:}

1. Los Angeles equipment consisting a cylindrical barrel diameter is $70 \mathrm{~cm}$ and height is $50 \mathrm{~cm}$, handled on a horizontal axis can be rotated around this axis with a speed of (30-33) RPM.

2. Balance.

3. Sieves of No. $12,12.5 \mathrm{~mm}$ and $10 \mathrm{~mm}$.

4. Iron or metallic balls, (11) numbers, diameter is $4.8 \mathrm{~mm}$ and weight of each is $445 \mathrm{gm}$.

5. Oven.

\section{ACCURACY AND SPECIFICATION:}

1. For high quality projects it should be less than $30 \%$.

2. For normal and low quality projects it should not pass $50 \%$.

\section{PROCEDURE:}

1. Put about $1000 \mathrm{gm}$ (W1) of the aggregate in the oven for drying.

2. Open the Los Angeles equipment and put the dried aggregate sample with the (11) balls in it and close it again.

3. Rotate the barrel for 500 times.

4. Take out the total sample and sieve it on sieve No. 12 .

5. Take the weight of passed material through sieve No. 12. (W2).

\section{OBJECTIVES:}

(i) To determine the Los Angeles abrasion value.

(ii) To find the suitability of aggregates for use in road construction.

\subsubsection{Theory:}

The aggregate used in surface course of the highway pavements are subjected to wearing due to movement of traffic. When vehicles move on the road, the soil particles present between the pneumatic tyres and road surface cause abrasion of road aggregates. The steel reamed wheels of animal driven vehicles also cause considerable abrasion of the road surface. Therefore, the road aggregates should be hard enough to resist abrasion. Resistance to abrasion of aggregate is determined in laboratory by Los Angeles test machine. The principle of Los Angeles abrasion test is to produce abrasive action by use of standard steel balls which when mixed with aggregates and rotated in a drum for specific number of revolutions also causes impact on aggregates. The percentage wear of the aggregates due to rubbing with steel balls is determined and is known as Los Angeles abrasion value.

\section{5: DETERMINATION OF THE AGGREGATE CRUSHING VALUE}

The 'aggregate crushing value' gives a relative measure of the resistance of an aggregate to crushing under a gradually applied compressive load. It is the percentage by weight of the crushed (or finer) material obtained when the test aggregates are subjected to a specified load under standardized conditions, and is a numerical index of the strength of the aggregate used in road construction.

Aggregates with lower crushing value indicate a lower crushed fraction under load and would give a longer service life to the road and hence a more economical performance. Weaker aggregates if used would get crushed under traffic loads, would produce smaller pieces not coated with binder and these would be easily displaced or loosened out resulting in loss of the surface/layer. In short the aggregates used in road construction must be strong enough to withstand crushing under roller and traffic. 


\section{OBJECTIVES}

(i) To determine crushing value of given road aggregates;

(ii) To assess suitability of aggregates for use in different types of road Pavements.

\section{APPARATUS}

The apparatus for the standard aggregate crushing test as per IS: 2386-1963 (Part IV) consists of the following:

(i) The test mould-a $15.2 \mathrm{~cm}$ diameter open-ended steel cylinder with square base plate; plunger having a piston of diameter 15 $\mathrm{cm}$, with a hole provided across the stem of the plunger so that a rod could be inserted for lifting or placing the plunger in the cylinder.

(ii) A straight metal tamping rod of circular cross-section $16 \mathrm{~mm}$ in diameter and 45 to $60 \mathrm{~cm}$ long, rounded at one end.

(iii) A balance of capacity $5 \mathrm{~kg}$, readable and accurate up to $1 \mathrm{gm}$.

The aggregates may be dried by heating at $100^{\circ}-110^{\circ} \mathrm{C}$ for not more than 4 hours and cooled to room temperature before testing, if necessary.

(i) Sieve the material through $12.5 \mathrm{~mm}$ and $10 \mathrm{~mm}$ IS sieves. The aggregates passing through $12.5 \mathrm{~mm}$ sieve and retained on $10.0 \mathrm{~mm}$ sieve comprise the test material.

(ii) Take about $3.25 \mathrm{~kg}$ of this material.

(iii) Pour the aggregates to fill about just more than 1/3rd depth of the measuring cylinder.

(iv) Compact the material by giving 25 gentle blows with the rounded end of tamping rod.

(v) Add two more layers in similar manner, such that the cylinder is full.

(vi) Remove the excess material with a straight edge. The quantity contained in the measuring cylinder is that amount of aggregates which will be used to prepare the test specimen.

(vii) Empty the cylinder and weigh the aggregates, accurate up to $1 \mathrm{gm}$.

(viii) Transfer the whole of this weighed quantity to the test mould by filling it in three layers in the same manner as for cylindrical measure. The total Experiment No. 1-Aggregate Crushing Value Test 3depth of the sample is then about $10 \mathrm{cms}$ and the surface a little below the top of mould.

(ix) Level off the surface and place the plunger over it so that it rests horizontally on the surface of the aggregates.

(x) Place this assembly on the pedestal of compression testing machine.

(xi) Apply the load at a uniform rate of 4 tonnes per minute until the total applied load is 40 tonnes.

(xii) Release the load.

(xiii) Take the aggregate out of cylinder and sieve them through $2.36 \mathrm{~mm}$ IS sieve. Weigh this fraction passing through it to an accuracy of $0.1 \mathrm{gm}$. This fraction is a measure of loss of material due to crushing.

(xiv) Note down the observations in the proforma and compute the aggregate crushing value. The mean of two observations, rounded to nearest whole number is reported as the 'Aggregate crushing value'. Test with Non-standard Sizes of Aggregates if required, or if the standard size is not available, test may be carried out with different gradings. However specifications will be different for such cases and

\section{PRECAUTIONS}

(i) The plunger should be placed centrally and rest directly on the aggregates. Care should be taken that it does not touch the walls of 4 Laboratory Manual in Highway Engineering the cylinder so as to ensure that the entire load is transferred onto the aggregates.

(ii) In the operation of sieving the aggregates through $2.36 \mathrm{~mm}$ sieve and weighing care should be taken to avoid loss of fines. The sum of weights of fractions retained, and passing the sieve should not differ from the original weight of the specimen by more than $1 \mathrm{gm}$. 
(iii) The tamping should be done properly by gently dropping the tamping rod and not by hammering action. Also the tamping should be uniform loss of the surface/layer. In short the aggregates used in road construction must be strong enough to withstand crushing under roller and traffic.

\section{6: DETERMINATION OF AGGREGATE IMPACT VALUE TEST}

The aggregate impact value indicates a relative measure of the resistance of aggregates under sudden shock or an impact. It differs in some aggregates from its resistance to a slow compressive load. Impact load assesses the sustainability of aggregates with regard to the toughness, for use in pavement construction. Hence, A test is necessary to evaluate the toughness of stones. Therefore, we call this the resistance to fracture under repeat impacts as an impact test for road stones as shown figure 3.

\section{Theory of Aggregate Impact Test}

The property of a material to resist impact is known as toughness. Due to movement of vehicles on the road the aggregates are subjected to impact resulting in their breaking down into smaller pieces. The aggregates should therefore have sufficient toughness to resist their disintegration due to impact. This characteristic is measured by impact value test. The aggregate impact value is a measure of resistance to sudden impact or shock, which may differ from its resistance to gradually applied compressive load. Without wedging or packing up on the level plate, block or floor, so that it is rigid and the hammer guide columns are vertical as shown in Fig 6.

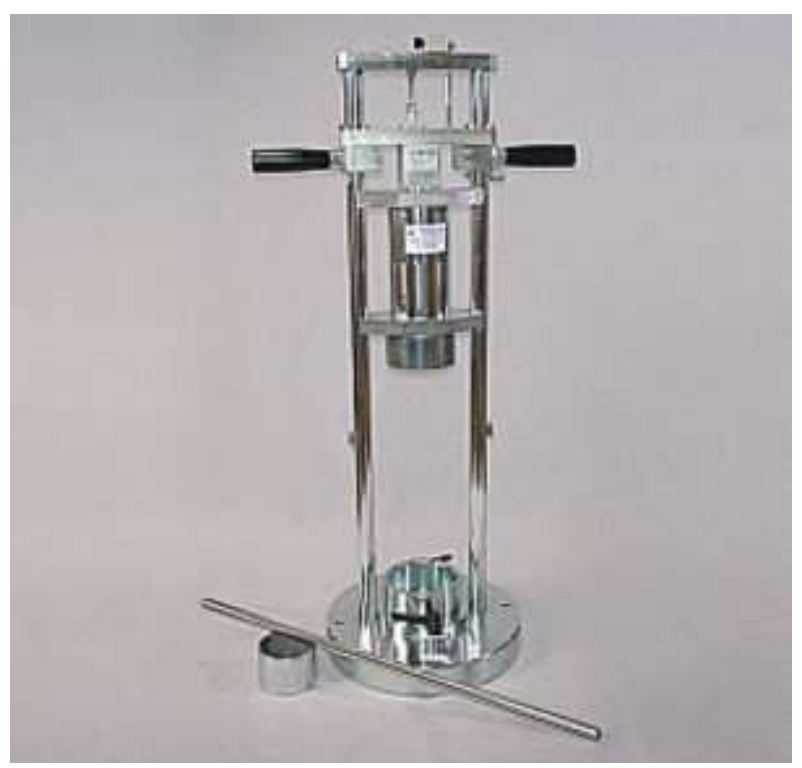

Figure 6: Impact Testing Machine

\section{Apparatus for Aggregate Impact Value Test}

The following are the Apparatus necessary to test the aggregate impact value as shown in Fig 7.

- Impact testing machine.

- Cylindrical measure.

- Internal diameter $=7.5 \mathrm{~cm}$.

- Depth $=5.0 \mathrm{~cm}$.

- $\quad$ Tamping rod $=23 \mathrm{~cm}$. long, $1 \mathrm{~cm}$ diameter.

- IS sieves $=12.5 \mathrm{~mm}, 10 \mathrm{~mm}$ and $2.36 \mathrm{~mm}$.

- Balance with weights.

- Oven (to maintain a temperature of $105 \pm 5^{\circ} \mathrm{C}$ ).

\section{Theory for Testing Coarse Aggregate for Impact value}

The aggregate impact value is nothing but the percentage of formation of fines after impact test in terms of total weight of the sample.

- Original weight of the oven dried sample $=\mathrm{W}_{1} \mathrm{~kg}$.

- The weight of the fraction passing $2.36 \mathrm{~mm}$ IS sieve $=\mathrm{W}_{2} \mathrm{~kg}$. 
- Aggregate impact value $=\mathrm{W}_{2} / \mathrm{W}_{1} * 100$ percent.

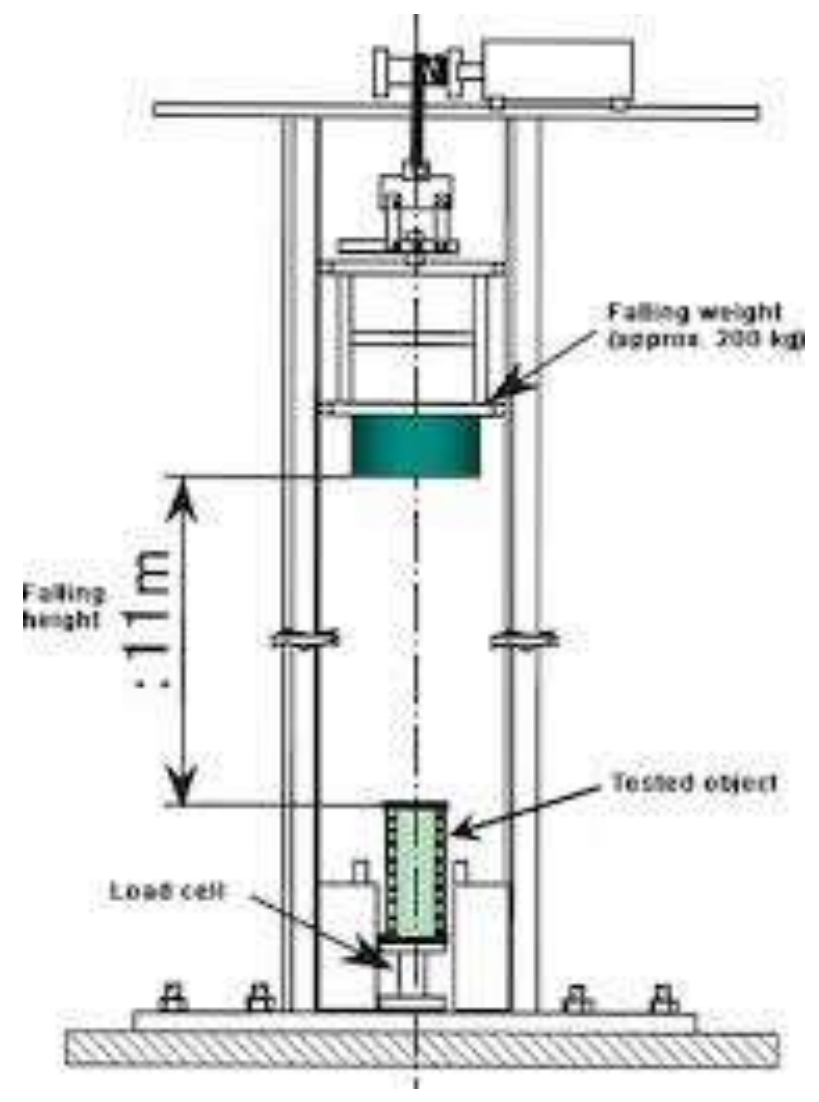

Figure 7: Impact Testing Machine

\section{Procedure for Aggregate Impact Test}

i. The test sample consists of aggregate passing through $12.5 \mathrm{~mm}$ IS sieve. It retains on $10 \mathrm{~mm}$ sieve, dried in an oven for four hours at a temperature of $100^{\circ} \mathrm{C}$ to $110^{\circ} \mathrm{C}$ and should cool it.

ii. Fill the cylindrical measure up to one-third full and tamp 25 times with the rounded end of the tamping rod.

iii. A further quantity of aggregate then adds up to about $2 / 3$ full in the cylinder and give 25 strokes by tampering rod. Fill the measure with aggregates to overflow and tamp 25 times.

iv. The surplus aggregate is struck off using the tamping rod.

v. We determine the net weight of aggregate in the measure to the nearest gram.

vi. The impact machine is placed with its bottom plate flat on the floor, so that the hammer guide columns are vertical.

vii. The cup is fixed firmly in position on the base of the machine and the whole of the test sample from the cylindrical measure is transferred to the cup and is compacted by tamping rod with 25 strokes.

viii. The hammer is raised until its lower face is $38 \mathrm{~cm}$ above the upper surface of the aggregate in the cup, and allows falling freely onto the aggregate.

ix. Give 15 blows to the test sample each being delivered at an interval of not less than one second.

x. Take the crushed aggregate on $2.36 \mathrm{~mm}$ sieve and sieve it until no further significant passes.

xi. Weigh the fraction passing $2.36 \mathrm{~mm}$ sieve.

\section{7: DETERMINATION OF FLAKINESS INDEX}

Flakiness index is the percentage by weight of particles in it, whose least dimension (i.e. thickness) is less than three-fifths of its mean dimension. Elongation index is the percentage by weight of particles in it, whose largest dimension (i.e. length) is greater than one and four-fifths times its mean dimension. 
Flaky and elongated particles may have adverse effects on concrete and bituminous mix. For instance, flaky and elongated particles tend to lower the workability of concrete mix which may impair the long-term durability. For bituminous mix, flaky particles are liable to break up and disintegrate during the pavement rolling process.

\subsection{1: Shape Tests on Coarse Aggregates:}

The following tests are conducted on coarse aggregates under shape tests:

The elongation index of the given aggregates

The flakiness index of the given aggregates

\section{Apparatus for Shape Tests}

The apparatus for the shape tests consists of the following:

1. A standard thickness gauge

2. A standard length gauge

3. IS sieves of sizes $63,5040,31.5,25,20,16,12.5,10$ and $6.3 \mathrm{~mm}$

4. A balance of capacity $5 \mathrm{~kg}$, readable and accurate up to $1 \mathrm{gm}$.

\section{Procedure of Shape Tests on Coarse Aggregates}

Sieve the sample through the IS sieves (as specified in the table).Take a minimum of 200 pieces of each fraction to be tested and weigh them. To separate the flaky materials, gauge each fraction for thickness on a thickness gauge. The width of the slot used should be of the dimensions specified in column (4) of the table for the appropriate size of the material. Weigh the flaky material passing the gauge to an accuracy of at least 0.1 per cent of the test sample.

To separate the elongated materials, gauge each fraction for length on a length gauge. The width of the slot used should be of the dimensions specified in column (6) of the table for the appropriate size of the material. Weigh the elongated material retained on the gauge to an accuracy of at least 0.1 per cent of the test sample.

\section{Record of Shape Test}

Flakiness Index $=\left(\mathrm{X}_{1}+\mathrm{X}_{2}+\ldots ..\right) /\left(\mathrm{W}_{1}+\mathrm{W}_{2}+\ldots\right) \mathrm{X} 100$

Elongation Index $=\left(\mathrm{Y}_{1}+\mathrm{Y}_{2}+\ldots\right) /\left(\mathrm{W}_{1}+\mathrm{W}_{2}+\ldots\right) \mathrm{X} 100$

\section{Recommended Values of Flakiness Index and Elongation Index}

The shape tests give only a rough idea of the relative shapes of aggregates. Flaky and elongated particles should be avoided in pavement construction, particularly in surface course.

If such particles are present in appreciable proportions, the strength of pavement layer would be adversely affected due to possibility of breaking under loads. Workability is reduced for cement concrete. IRC recommendations for maximum limits of flakiness index are given as $30 \%$. 
International Journal of Advances in Scientific Research and Engineering (ijasre), Vol 7 (9), September -2021

\section{0: DATA PRSENTATION AND INTERPRETATION}

\section{1: Data Presentation}

The average modal composition of rock from Mista Ali Granite as observed from thin section under plane and cross polarized light is shown in Table 7, while the strength indices as measured from the testing machines are summarized in subsequent Tables. In both Megascopic and Microscopic observations of minerals in rock, Mista Ali Granite is composed of the following minerals as shown in Fig 8.
i. Quartz
ii. orthoclase
iii. $\quad$ Albite
iv. Microcline
v. Biotite
vi. Hornblende
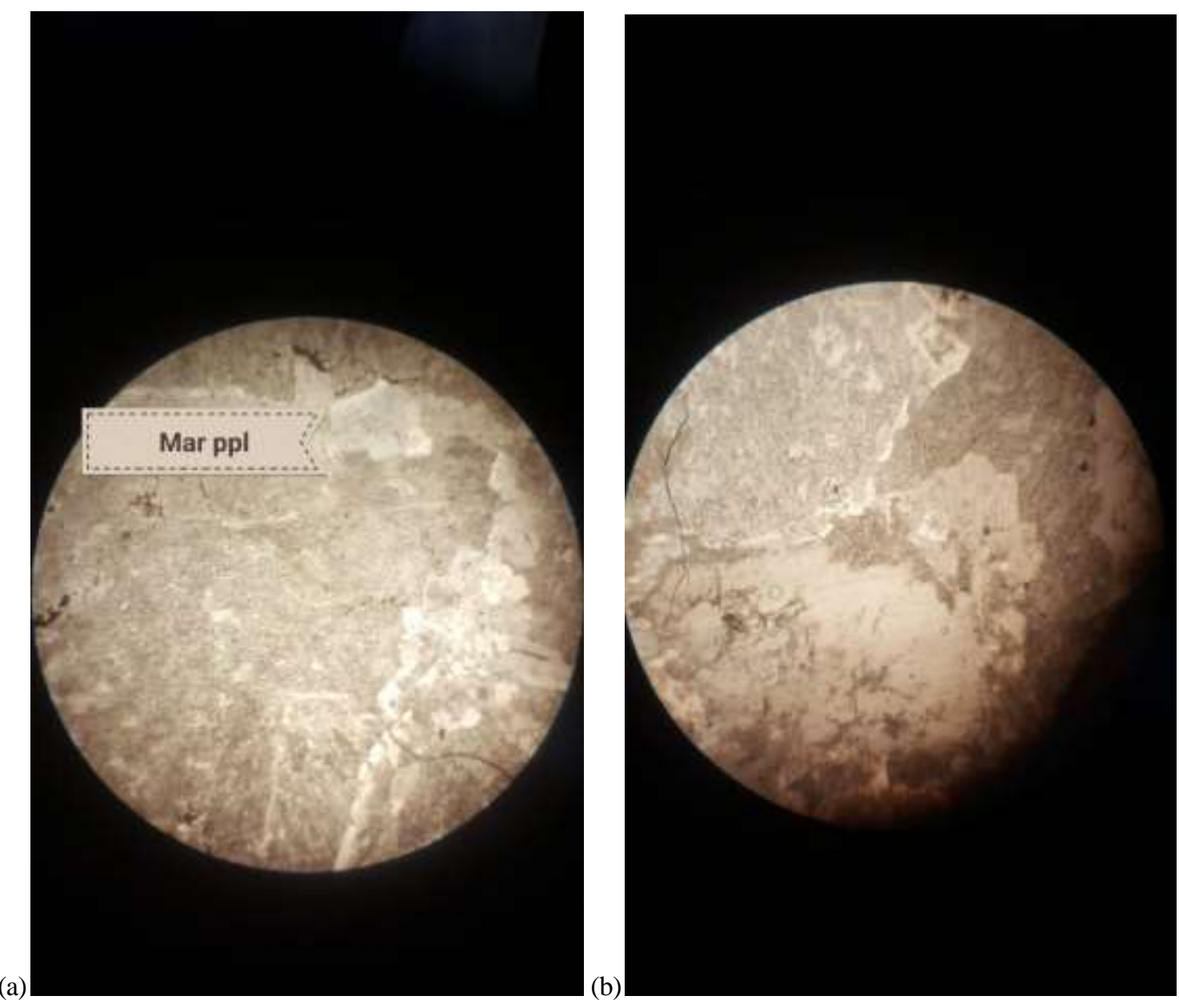

Figure 8: Photomicrograph Mista Ali Granite (a) Under PPL, (b) Under XPL

Table 7: Average Modal composition of Granite from Mista Ali

\begin{tabular}{|l|l|l|l|}
\hline Mineral & JC001 (\%) & JC002 (\%) & JC008 (\%) \\
\hline Quartz & 30 & 29 & 30 \\
\hline Orthoclase & 26 & 23 & 25 \\
\hline Plagioclase & 35 & 36 & 35 \\
\hline Biotite & 5 & 7 & 5 \\
\hline
\end{tabular}


International Journal of Advances in Scientific Research and Engineering (ijasre), Vol 7 (9), September -2021

\begin{tabular}{|l|l|l|l|}
\hline Microcline & 3 & & \\
\hline Hornblende & 4 & 3 & 4 \\
\hline Others & 3 & 2 & 1 \\
\hline
\end{tabular}

\subsubsection{Determination of Granite as an Aggregate using Los Angeles Abrasion Value (AAV)}

The aggregate used in surface course of the highway pavements are subjected to wearing due to movement of traffic. When vehicles move on the road, the soil particles present between the pneumatic tyres and road surface cause abrasion of road aggregates. The steel reamed wheels of animal driven vehicles also cause considerable abrasion of the road surface. Therefore, the road aggregates should be hard enough to resist abrasion. Resistance to abrasion of aggregate is determined in laboratory by Los Angeles test machine. The principle of Los Angeles abrasion test is to produce abrasive action by use of standard steel balls which when mixed with aggregates and rotated in a drum for specific number of revolutions also causes impact on aggregates. The percentage wear of the aggregates due to rubbing with steel balls is determined and is known as Los Angeles Abrasion Value.

\section{A: JC QUARRY}

Table 8: Los Angeles Abrasion Test from JC Quarry

\begin{tabular}{|l|l|l|l|l|l|}
\hline & JC 1 & JC 2 & JC 3 & JC 4 & JC 5 \\
\hline Original weight of aggregate sample $=\mathrm{W}_{1} \mathrm{~g}$ & 5000 & 5000 & 5000 & 5000 & 5000 \\
\hline Weight of aggregate sample retained $=\mathrm{W}_{2} \mathrm{~g}$ & 3726 & 3695 & 3681 & 3701 & 3693 \\
\hline Weight passing 2.36mm IS sieve $=\mathrm{W}_{1}-\mathrm{W}_{2} \mathrm{~g}$ & 1274 & 1305 & 1319 & 1299 & 1307 \\
\hline Abrasion Value $=\left(\mathrm{W}_{1}-\mathrm{W}_{2}\right) / \mathrm{W}_{1} \mathrm{X} 100$ & & & & & \\
\hline Mean Aggregate Abrasion value & 25.48 & 26.09 & 26.14 & 25.98 & 26.14 \\
\hline
\end{tabular}

\subsection{3: DETERMINATION OF GRANITE AS AN AGGREGATE USING AGGREGATE CRUSHING VALUE (ACV)}

The average crushing value is defined as a ratio of the weight of fines passing the specified IS sieve to the total weight of the sample expressed as a percentage.

Average Crushing Value $=100 \mathrm{~W}_{2} / \mathrm{W}_{1}$,

$$
\begin{aligned}
& \mathrm{W}_{1}=\text { total weight of the dry sample } \\
& \mathrm{W}_{2}=\text { Weight of the portion of the crushed passing } 2.36 \mathrm{~mm} \text { IS Sieve. }
\end{aligned}
$$

Table 22: Aggregate Crushing Value test from JC Quarry

\begin{tabular}{|l|l|l|l|l|l|}
\hline & JC 1 & JC 2 & JC 3 & JC4 & JC5 \\
\hline Original weight of aggregate sample $=\mathrm{W}_{1} \mathrm{~g}$ & 3603 & 3706 & 3680 & 3672 & 3603 \\
\hline Weight passing 2.36mm IS sieve $=\mathrm{W}_{1}-\mathrm{W}_{2} \mathrm{~g}$ & 904 & 1002 & 1000 & 900 & 900 \\
\hline Abrasion Value $=\left(\mathrm{W}_{1}-\mathrm{W}_{2}\right) / \mathrm{W}_{1} \mathrm{X} 100$ & 25.09 & 27.03 & 26.80 & 27.72 & 27.03 \\
\hline Mean Aggregate Crushing Value & \multicolumn{3}{|l}{} \\
\hline
\end{tabular}




\subsection{3: DETERMINATION OF GRANITE AS AN AGGREGATE USING AGGREGATE IMPACT VALUE (ACV)}

The average Impact value is define as a ratio of the weight of fines passing the specified IS sieve to the total weight of the sample expressed as a percentage.

Average Impact Value $=100 \mathrm{~W}_{2} / \mathrm{W}_{1}$,

$\mathrm{W}_{1}=$ total weight of the dry sample

$\mathrm{W}_{2}=$ Weight of the portion of the crushed passing $2.36 \mathrm{~mm}$ IS Sieve.

\section{A: JC QUARRY}

OBSERVATIONS:

Original weight of aggregate sample $=\mathrm{W}_{1} \mathrm{~g}$

Weight passing $2.36 \mathrm{~mm}$ IS sieve $=\mathrm{W}_{2} \mathrm{~g}$

Impact Value $=\left(\mathrm{W}_{2} / \mathrm{W}_{1}\right) \times 100$

Table 26: Aggregate Impact Value Test from JC Quarry

\begin{tabular}{|l|l|l|l|l|l|}
\hline & JC 1 & JC 2 & JC 3 & JC4 & JC5 \\
\hline Original weight of aggregate sample $=\mathrm{W}_{1} \mathrm{~g}$ & 692 & 698 & 701 & 698 & 693 \\
\hline Weight passing 2.36mm IS sieve $=\mathrm{W}_{1}-\mathrm{W}_{2} \mathrm{~g}$ & 121 & 116 & 120 & 116 & 120 \\
\hline Impact Value $=\left(\mathrm{W}_{1}-\mathrm{W}_{2}\right) / \mathrm{W}_{1} \mathrm{X} 100$ & 17.1 & 16.6 & 17.1 & 17.1 & 17.1 \\
\hline Mean Aggregate Impact Value & \multicolumn{5}{|l|}{17.1} \\
\hline
\end{tabular}

\subsection{4: DETERMINATION OF GRANITE AS AN AGGREGATE USING FLAKINESS INDEX TEST}

Flakiness Index Test is defined as a ratio of the weight of fines passing the specified IS sieve to the total weight of the sample expressed as a percentage.

Flakiness Index Test $=100 \mathrm{~W}_{2} / \mathrm{W}_{1}$,

$\mathrm{W}_{1}=$ total weight of the dry sample

$\mathrm{W}_{2}=$ Weight of the portion of the crushed passing $2.36 \mathrm{~mm}$ IS Sieve.

\section{A: JC QUARRY}

\section{OBSERVATIONS:}

Original weight of aggregate sample $=\mathrm{W}_{1} \mathrm{~g}$

Weight passing $2.36 \mathrm{~mm}$ IS sieve $=\mathrm{W}_{2} \mathrm{~g}$

Flakiness Index Test $=\left(\mathrm{W}_{2} / \mathrm{W}_{1}\right) \mathrm{X} 10$

Table 30: Flakiness Index Test from JC Quarry

\begin{tabular}{|l|l|l|l|l|l|}
\hline & JC1 & JC2 & JC3 & JC4 & JC5 \\
\hline Original weight of aggregate sample $=\mathrm{W}_{1} \mathrm{~g}$ & 769 & 721 & 701 & 720 & 768 \\
\hline Weight passing 2.36mm IS sieve $=\mathrm{W}_{1}-\mathrm{W}_{2} \mathrm{~g}$ & 104 & 103 & 120 & 102 & 103 \\
\hline Flakiness Value $=\left(\mathrm{W}_{1}-\mathrm{W}_{2}\right) / \mathrm{W}_{1}$ X 100 & 13.5 & 14.3 & 17.1 & 17.0 & 13.3 \\
\hline Mean Flakiness Index Test & & 13.9 & \\
\hline
\end{tabular}


International Journal of Advances in Scientific Research and Engineering (ijasre), Vol 7 (9), September -2021

\section{5: DETERMINATION OF GRANITE AS AN AGGREGATE USING SPECIFIC GRAVITY METHOD}

Specific granite of fine aggregate has been determined using Picnometer Test. Three trials have been conducted and average specific gravity is considered. The details are presented below;

$\mathrm{G}=\mathrm{W} 2-\mathrm{W} 1 / \mathrm{W} 2-\mathrm{W} 1(\mathrm{~W} 3-\mathrm{W} 4)$

$\mathrm{W} 1=\mathrm{Wt}$ of empty Pycnometre

$\mathrm{W} 2=\mathrm{Wt}$ of Pycnometre $+1 / 3$ of fine Aggregate

$\mathrm{W} 3=\mathrm{Wt}$ of Pycnometre $+1 / 3$ of F.A + Water

W4 = Wt of Pycnometre + Wt of Water Full of Pycnometre

Table 34: Crushed Aggregate in JC

\begin{tabular}{|l|l|l|l|l|l|}
\hline Number of Trials & W1 & W2 & W3 & W4 & G \\
\hline 1 & 433.5 & 775.8 & 1095.6 & 884.2 & 2.615 \\
\hline 2 & 433.9 & 784.8 & 1100.9 & 884.2 & 2.615 \\
\hline Average & & & & & 2.615 \\
\hline
\end{tabular}

\section{B: Crushed Sand in JC}

Table 35: Crushed Sand in JC

\begin{tabular}{|l|l|l|l|l|l|}
\hline Number of Trials & W1 & W2 & W3 & W4 & G \\
\hline 1 & 433.7 & 704.0 & 1050.8 & 884.2 & 2.601 \\
\hline 2 & 433.8 & 709.1 & 1054.8 & 884.2 & 2.629 \\
\hline Average & & & & & 2.615 \\
\hline
\end{tabular}

\subsection{INTERPRETATION OF RESULT}

The average modal composition of minerals from Mista Ali Granite as observed from thin section under plane and cross polarized light is shown in Table 17, while the strength indices are summarized in tables 16 to 31 . The high resistance of granite to pressure could be attributed to the fact that granite is an intrusive igneous rock with quartz $\left(\mathrm{SiO}_{2}\right)$, potassium feldspar, orthoclase $\left(\mathrm{KAlSi}_{3} \mathrm{O}_{8}\right)$ and biotite mica $\left[\mathrm{k}\{\mathrm{Mg}, \mathrm{Fe}\}_{3}\left\{\mathrm{AlSi}_{3} \mathrm{O}_{10}\right\}\{\mathrm{OH}\}_{2}\right]$ as the major mineralogical composition. The rock is formed from silicate melts in which the silica content is greater than $66 \%$. It is even- grained and entirely crystalline with grain boundaries interlocked. There is therefore no plane of weakness in the rockmass. Therefore the above composition of the granite observed from thin section under plane and cross polarized light is traced to the cooling history of the granite. The cooling history depends on the temperature of rock under 1 atmospheric pressure. As temperature falls during crystallization of magma, more minerals will come out of the magma, thereby increasing the gradient of the rock, making the rock more durable to withstand external load and abrasion, thereby having high inter-crystallinity.

The high inter-crystallinity (interlocking) of granite as a result of more minerals gives granite its elastic property. According to Hook law (1666), when a load is applied to an elastic material (granite), it will to its maximum position and return to its original position when the applied load is withdrawn. This gives granite a better property to withstand stress than other rocks.

From table 17, the high percentage of quartz and alkali feldspar gave the granite its high elastic property. Table 38 shows the average values of Granite in different point at JC Quarry site in Mista Ali using different Testing Machines and Table 39 shows the Average Specific Gravity of Granite in different points aat JC Quarry site in Mista Ali using Picnometer. Its low percentage measured from percentage pass indicates that more energy is required to dislodge or disaggregate the rock particle. The energy required to do this is called comminution energy. Because granite has a potential energy to overcome an external energy applies to it, it is better option for an aggregate for building, road and other engineering construction. The lower the percentage pass, the better its use as road surfacing and building construction. 
From Figure 9 and Table 21, the average abrasion value for different samples of different points at JC quarry is $11.0 \%$. The value indicates that JC quarry site possess good value for an aggregate for road surfacing. This is because the standard aggregate value is less than $30 \%(\mathrm{AAV} \leq 30 \%)$ and the values obtained from the quarries are less than $30 \%$ making it good for road surfacing and other construction disciplines.

From Figure10 and Table 25 the average aggregate crushing value for different samples from different points at JC quarry, is $26.06 \%$. This value indicates that JC Quarry possesses good quality for road construction. This is because the standard aggregate crushing value is less or equal to $30 \%(\mathrm{AAV} \leq 30 \%)$ and the value obtained from quarry is less than $30 \%$ making it good quality for road surfacing and other engineering disciplines.

From Figure 11 and Table 29, the aggregate impact values for different samples from different points at JC quarry is $17.1 \%$. This value indicates that JC quarry possesses good quality for road surfacing. This is because the standard value for aggregate impact value is less or equal to $30 \%$, making it good quality for road surfacing and other civil engineering disciplines.

From figure 12, and Table 33, the franklin index test for different samples from different points at JC quarry is $13.9 \%$. This value indicates JC quarry possesses good quality for road surfacing. This is because the standard value for franklin index test is less or equal to $30 \%$ (FI $\leq 30 \%$ ) and the values obtained from this quarry is less than $30 \%$, making good quality for road surfacing and other civil engineering disciplines.

The average specific gravity of granites in JC quarry is 2.615 , (Table 40) and fall within the range of standard specific gravity of granite, hence, used to assess the suitability of granite as an aggregate quarry and this is shown in tables 35 . In comparing the specific gravities of granites of different points at JC quarry site in Mista Ali, the one with a specific gravity closer to a standard specific gravity value is one more suitable for an aggregate quarry. This is related to the mineral compositions of granite such as quartz, orthoclase, hornblende, biotite, and microcline. These mineral compositions that make up the Granites have their specific gravity greater or less than 2.650 . This is the reason why granites have their specific gravities range from 2.600 to 2.700 . Therefore any granite with specific gravity that falls within this range is suitable for use as an aggregate quarry. In this case, samples collected from different points at JC quarry site in Mista Ali possess these specific gravities and hence are suitable for use as aggregates.

Chart1, 2, 3 and 4, represent the angles made by percentage pass using AAV, AIV, FI and ACV. The lower values of the each of the angles made by the percentage pass indicate that Mista Ali Granites possess a good road surfacing quality and hence recommending it as an Aggregate quarry. The angles made by percentage pass of AAV, AIV, FI and ACV ranges from $40^{\circ}$ to $94^{\circ}$ thereby making a good road surfacing.

The standard value for good road surfacing for crushing value, impact value, index test and abrasion value is less $30 \%$ (Table 41 and figure 13) and less than $108^{0}$.

Table 41: Average parameter Values of Granites in different quarry Sites using

\begin{tabular}{|l|l|l|}
\hline $\begin{array}{l}\text { TEST } \\
\text { METHOD }\end{array}$ & $\begin{array}{l}\text { RRC } \\
\text { QUARRY }\end{array}$ & $\begin{array}{l}\text { STANDARD } \\
\text { VALUE }\end{array}$ \\
\hline $\begin{array}{l}\text { IMPACT } \\
\text { VALUE }\end{array}$ & 13.90 & 30 \\
\hline $\begin{array}{l}\text { CRUSHING } \\
\text { VALUE }\end{array}$ & 26.10 & 30 \\
\hline $\begin{array}{l}\text { ABRASION } \\
\text { VALUE }\end{array}$ & 25.79 & 30 \\
\hline $\begin{array}{l}\text { Flakiness Index } \\
\text { Test }\end{array}$ & 13.90 & 30 \\
\hline
\end{tabular}

Table 42: Average Specific Granite of Granites in Different Quarry Sites in fobur using Picnometer

\begin{tabular}{|l|l|l|l|l|l|l|}
\hline Quarry & \multicolumn{2}{l|l|l|}{ Crushed Aggregate } & \multicolumn{2}{l|}{ Crushed Sand } & Crushed Aggregate & Crushed Sand \\
\hline & 1 & 2 & 1 & 2 & Average & Average \\
\hline JC & 2.615 & 2.615 & 2.601 & 2.629 & 2.615 & 2.615 \\
\hline
\end{tabular}


International Journal of Advances in Scientific Research and Engineering (ijasre), Vol 7 (9), September -2021

\section{0: SUMMARY, CONCLUSION AND RECCOMMENDATIONS}

\section{$5.1 \quad$ Summary}

The standard value for granite as an aggregate for construction materials as a road surfacing, building and other civil engineering works, using testing parameters such as Los Angeles abrasion test (LAA), aggregate impact value (AIV), aggregate crushing value (ACV), and flakiness index test (FI) is less than $30 \%$ and it is shown in relevant tables and figures, likewise the specific gravity.

Using all these testing parameters to test for granite for use as an aggregate for construction, it is observed that, the smaller the quantity of fines obtained or that can pass through the sieve, the better the granite as an aggregate.

Application of these testing methods to Mista Ali granite provides the following observations;

1. Average Impact Value (AIV) as represented in Table 29, for JC, is less than $30 \%$, such that $\mathrm{JC}=17.1 \%$,

2. Average Crushing Value (ACV) as represented in Table 25, for JC, is less than $30 \%$, such that $\mathrm{JC}=26.1 \%$,

3. Average Abrasion Value (AAV) as represented in Table 21, for RRC, is less than $30 \%$, such that JC $=25.79 \%$,

4. Flakiness Index Test (FI) as represented in Table 33, for JC, is less than $30 \%$, such that $\mathrm{JC}=13.90 \%$,

Therefore, from the above values using testing machine methods, granite from JC quarry is of higher grade for construction material.

In the same line of reasoning, application of picnometer to measure specific gravity of Mista Ali granite provides the following observations;

i. For JC as shown in Table 40;

a. $\quad$ average crushed aggregate $=2.615$

b. $\quad$ average crushed sand $=2.616$

Therefore, the above values fall within the standard value of specific gravity of granite, hence, suitable for use as an aggregate quarry.

\section{2: Conclusion}

The samples collected from different quarry points JC, in Mista Ali, were subjected to different Testing methods and the values obtained from the samples were less than the standard values with range of values from 10 to 29\%, therefore it is concluded that Mista Ali granite is of high quality as an aggregate suitable for construction. However, granite obtained from JC quarry with values of JC $=17.1 \%$, is of higher grades when compared to the standard value.

Similarly, it is also concluded that, because the specific gravity of granite in Mista Ali falls within the standard value, which is less or equal to $30 \%$, it is suitable for use as an aggregate quarry.

\section{3: Recommendations}

After rigorous analyses of Mista Ali Granites of different points at JC quarry site, using different testing machines, the following recommendations were made;

i. Mista Ali Granites meet the standard values for road and building construction and recommended as an aggregate for construction material.

ii. JC Quarry has value of $17.1 \%$, better than the standard value and hence recommended as an aggregate for construction material.

iii. Los Angeles test is commonly used to evaluate the hardness of aggregates. The test has more acceptability because the resistance to abrasion and impact is determined simultaneously and is a better recommended testing machine.

\section{REFERENCES}

1. Abuwubu, J.,A. Al Dwairi, R. A., Hadi, Na. A., Markel, B., Danger, V., Laila, H. A., (2016) Geological and Engineering Properties of Granite Rocks from Aqaba Area, South Jordan. Geomaterials, 6, 18-27.

2. America Society for Testing and Materials (ASTM) 170. Standard Testing Method for Compressive strength of Dimension Stone (2008).

3. America Society for Testing and Materials (ASTM) 170. Standard Test Method for Laboratory Determination of Pulse Velocities and Ultrasonic Elastic constants of Rock. 1(2): 45. 
International Journal of Advances in Scientific Research and Engineering (ijasre), Vol 7 (9), September -2021

4. Amethyst Galleries Inc. Mineral Gallery. (2014). 2 (1) 21-23.

5. Arora V.L. (1987). Strength and deformation behavior of jointed rocks, Ph.D. Thesis Indian institute of Technology Delhi.

6. Barton N. (1993). The influence of joint properties in modeling jointed rock masses, Proc. $8^{\text {th }}$ Int. Congr. Rock.Mech, 1:1023-32.

7. Barton N. (2002): Some new Q-value correlations to assist in site characterization and tunnel design, Int. J. Rock. Mech. Min. Sci. Geomech. Abstr., 39:2:185-216.

8. Barton N. Lien R and kunle J. (1974): Engineering Classification of rock masses for the design of tunnel support, J. Rock Mech., 6:4: 189-236.

9. Barton N., (1976): Recent experience with Q-system for tunnel support, Proc. Symp Exploration for rock Engineering, Z. T., Bieniawski (Ed.), A. A. Balkema, Rotterdam, 1:107-114.

10. Beniawski Z. T. (1973): Case studies: Prediction of rock mass behavior by geomechanics classification, Proc. $2^{\text {nd }}$ Aust-NZ., Conf. Geomech, Brisbon, Pp. 36-41.

11. Beniawski Z. T. (1976): Rock Mass classification in rock engineering, Proc. Symp, Exploration for Rock Engineering, Z. T. Bieniawski (Ed.), A. A. Balkema, Rotterdam, 1:97-106.

12. Beniawski Z. T. (1978): Determination of rock mass deformation: Expereince from case histories, Inst. J. rock Mech and Min. Sci., 15: $237-247$.

13. Beniawski Z. T. (1984): Rock mechanics Design in Mining and Tunneling, A.A. Balkema, Rotterdam.

14. Beniawski Z. T. (1988): Rock Mass rating systems in engineering practice, symp on Rock classification systems for engineering purposes, ASTM, STP 984, Pp. 17-34.

15. Beniawski Z. T. (1989): Classiication of rock mass for engineering: The RMR system and future trends, comprehensive Rock Engineering, J. A. Hudson (Ed.), 3:553-573.

16. Beniawski Z. T. (1989): Engineering Rock mechanics classification, Wiley-Interscience, New York.

17. Berridge, N. G., (1971). The Jarawa Complex and the Geol of the Jos Plateau. Bull. Geol. Survey of Nigeria, 2 (32); 85-87.

18. Bieniawski L. T. (1973): Engineering Classification of jointed rock masses. Trans S. African Instn: (i.e. engrs., 15:12: 335-344.

19. Broch, E., Franklin J. A., (1972). “The point load strength test”, Int. J. Rock Mechanics and Mining Science, 9(6) 669-97.

20. Brown, E. T. (1981). ISRM.Rock Characterization, Testing and monitoring". ISRM Suggested Methods. Commission on Testing Methods, International Society for Rock Mechanics (ISRM(, Pergamon Press, Oxford, UK., 75 - 105.

21. Carter B. J. Duncan E. Scott J. and Lajtai E. Z. (1991).Fitting Strength criteria to intact rock, Int. J. Geotech and Geology Engineering, 9:73-81.

22. Coates D.F. (1964): Classification of Rock and rock masses, Int. J., Rock. Mech and Min. Sci, 1:421-429.

23. Cupta A. S. (1997): Engineering behavior and classification of weathered rocks, PhD. Thesis, Indian Institute of Technology Delhi.

24. Cupta A. S. and Rao K. S. (2000): Weathering effects on the strength and deformational behavior of crystalline rocks under uniaxial compression state int. J. Eng. Geol. 56:257-274

25. Cupta A. S. and Rao, K. S. (2001): Weathering indices and their applicability for crystalline rocks, Bull. Eng. Geol. Ene, 60:201-221.

26. Deere D. U. (1964): Technical description of rock cores for engineering purposes, felsmechnik and Inge-nieur-geologie, 1:1:16-22.

27. Deere D. U. (1968): Geological considerations rock mechanics in Engineering practice, Stagg K. G. and Zienkiewiks. O.C. (Eds), Wiley London, Pp. 1-19.

28. Deere D. U. Hendon A. J., Patton, F. D. and Cording E. J. (1966): Design of surface and near surface construction in rocks. Proc. $28^{\text {th }}$.US.Symp. Rock Mech., Mineapolis, Pp. 237-303.

29. Deere D. U., Miller R. P. (1966): Engineering classification and index properties for intact rocks, Tech Report no. AFNLTR- 65 116, Air Force Weapons Laboratory, New Mexico.

30. Fitches, W. R., Ajabade, A. C., Egbuniwe, I. G., (1985).R. W. Hott and J. B. Wright.Late Proterozoic Schist.

31. Franklin J. A. Broch E. and Walton G. (1971): Logging the mechanical character of rock, Trans. Instn. Min and Metilondon 80A: 18. 
International Journal of Advances in Scientific Research and Engineering (ijasre), Vol 7 (9), September -2021

32. Hakki W., (1971). The Mineral Exploration of the Aqaba Granites.The Hashemite Kingdom of Jordan. Natural Resources Authority, Mineral Resources Division Report, 31,45-56.

33. Hansagi I. A. (1965): Numerical determination of mechanical properties of rock and of rock masses, Int. J. rock Mech and Min. Sci, 2:219-223.

34. Hansagi I. A. (1974): Method of determining the degree of fissuration of rock, Int. J. Rock Mech and GeomechAbst, 11:379-388.

35. Hobbs N. B. (1974): Factors affecting the production of settlement of structures on rocks with particular reference to the chalk and trias, cent. On settlement of structures Brit. Geotech Soc., Pentech Press, London, Pp. 579-610.

36. Hoek E. (1994): Strenght of rock and rock masses, ISRM News Journal, 2(2): 4-16.

37. Hook E. and Brown E. T. (1980): Empirical Strength criterion for rock masses, J. Heotech. Engg.Die., ASCE, 106: GT9: 1013-1035.

38. Irfan, T. Y., (1996). Mineralogy, Fabric Properties and Classification of Weathered granites in Hong Kong.Quarterly Journal of Engineering Geology. 29(1): 5-35.

39. ISRM (1978): Standardization of Laboratory and filed tests, Inst. J. of Rock Mech and Min. Sci and Geomech. Alst., 15:348.

40. ISRM (1981): Basic technical description of rock masses, Int. J. of Rock Mech and Min. Sci. and Geomech. Abst., 18-85 - 110.

41. Kalamaras G. S. and Bieniawski Z. T. (1995). A rock strength concept for coal deamsincorporating the effect of time, Proc. $8^{\text {th }}$ Int. Congr. Rock Mech., 1:295 - 302.

42. Kogbe, C. A. (1979). Geology of Nigeria Elizabethan Publishing House Lagos, Nigeria 1:1-10.

43. Map Data, Google imaginary GNES/Astrim/Sptimage-Digital Land Sat - 1/08/2016 13:24

44. Mealeod, W. N., Turner, D. C. (1971). The Younger Granite 2a Geology of 30s Plateau, Geol. Survey of Nigeria, 32 (1) $48-90$.

45. Minipal -4 Model, (2014). Energy Dispersive X-Ray Fluorescence Spectrometer (ED-XRFS) PAN analytical B. V. Lelyyegl. 7602 E. A., Almelo, the Netherlands. 3-9.

46. Ojo, O., Olaleye, B. A., (2004). Classification of Ondo State intact Rock for Engineering purpose. Journal of Science Engineering and Technology. 11(3): 5753-5759.

47. Ramamarth T. (2001): Shear Strength responses of some geological materials in triaxial compression, Int. J. Rock Mech and Min. Sci. 38: 683-397.

48. Ramamarthy T. (1986): Stability of rock mass, $8^{\text {th }}$ IGS, Annual lecture, Ind. Geotech. J. 16:1:1-74.

49. Ramamarthy T. (1995): Bearing Capacity of rock foundations, Proc. Int workshop on Rock Foundations, Japan, A. A. Balkema, Rotterdam, Pp. 311-316.

50. Rammarthy T. (2004): A geo-engineering Classification for rocks and rock masses, Int. J. Rock Mech. Min. Sci., 41-1:89-101.

51. Rocha, M. (1964): Mechanical behavior of rock foundations in concrete dams, Trans. $8^{\text {th }}$ Cong. Large Dams, Edinbrugh, 1964, paper R-44, Q28: 785-832.

52. Serafim J. L. and PereiraJ. (1983): Consideration of the geomechanics classification of Bieniawski. Proc. Int. Symp. On Engg.Geology and Underground construction, Lisbon, Portugal, pt. 11, pp. 33-44.

53. Stapledon D. H. (1968): Discussion of D. G. Coates, rock classification, Int. J. Rock Mech. Min Sci., 5:371-373.

54. Terghazi K. (1946): Rock defects and load on support, rock tunneling with steel supports, R. V. Proctor and T. White (Eds.), Commercial shearing co. Youngstown, Ohio, Pp. 15-99.

55. Truswell. J. F., Cope, R. N., (1963). The Geology of parts of Niger and Zaria Provinces, Northern Nigeria.Published by geological survey of Nigeria. 29(1) 17-22.

56. Tugral A., Zarif., (1999). Correlation of Mineralogical and Textural Characterization with engineering properties of selected Granite htt[://www.sciencedirect.com/scienceretrieved. Jn 14, 2008: 303-315.

57. Van Breemar, O., Pegeon R. T., Bowden P. (1977). Age and isotopic studies of some Pan African granite from central ngieria. Res., 4, 307-319.

58. Wills, B. A.M., (2006).Mineral Processing technology. New York: Elsexier Science and Technology Books. 6 (1) 75-83. 